Savunma Bilimleri Dergisi

The Journal of Defense Sciences

Mayıs/May 2017, Cilt/Volume 16, Sayi/Issue 1.

ISSN (Bas111) : 1303-6831 ISSN (Online): 2148-1776

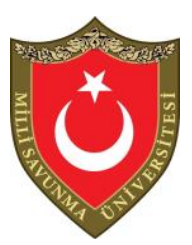

\title{
Sources of Conflict in the Middle East: Borders or Stratified Identities?
}

\author{
Doç.Dr.Kürşad TURAN ${ }^{1}$
}

\begin{abstract}
Since the end of Ottoman control, Middle East has experienced a large number of conflicts. The arrangements made at the end of World War I are often blamed for these conflicts. Arbitrarily drawn borders and the creation of influence zones between Great Britain and France without paying attention to religious and ethnic divisions present in the region are seen at the source of today's conflicts. Arangements such as the Bunsen Committee report, Sykes-Picot agreement, and Hussein-McMahon correspondence shaped the region after the war, but none of these were successfully implemented due to changing circumstances, and their contradicting nature. This study argues that even though these constituted the first step in the creation of the modern Middle East, the real cause of today's conflicts lie in the creation of a stratified politicized identity system that emerged through stages over the past century. These stages were marked by the conflicts between Arab nationalism and nation state identities; the politicization of sectarianism; and finally the emergence of ethnicity in politics.
\end{abstract}

Keywords: Middle East, conflict, Sykes-Picot agreement, Arab nationalism, sectarianism, ethnicity.

\section{Ortadoğu'da Çatışmanın Kaynakları: Sınırlar mı, Katmanlı Kimlikler mi?}

$\ddot{o} z$

Bölgede Osmanlı kontrolünün sona ermesinin ardından Ortadoğu çok sayıda çatışmaya sahne oldu. Bu çatışmalardan genellikle Birinci Dünya Savaşı sonrası yapılan düzenlemeler sorumlu tutuluyor. Keyfi olarak çizilen

\footnotetext{
1 Doç.Dr., Gazi Üniversitesi İktisadi ve İdari Bilimler Fakültesi, kturan@gazi.edu.tr
} 
sinırlar, Büyük Britanya ve Fransa arasında mevcut dini ve etnik farklılıklar dikkate alınmadan belirlenen etki alanları bugünün çatışmalarının kaynağ olarak görülüyor. Bunsen Komitesi raporu, Sykes-Picot antlaşmasi ve Hüseyin-McMahon yazlşmalarl gibi düzenlemeler bölgeyi savaş sonrasında şekillendirdi, ancak bunların hiç biri değişen şartlar ve birbirleriyle çelişmeleri yüzünden tam olarak uygulamaya konulamadı. Bu çalışma bu düzenlemeler modern Ortadoğu'nun yaratılmasında ilk adımı oluşturmasına rağmen bugünün çatışmalarının gerçek nedeninin geçen yüzyıl boyunca aşamalı olarak ortaya çıkan politize olmuş katmanlı kimlik sistemi olduğunu öne sürüyor. Bu aşamaları oluşturan çatışmalar Arap milliyetçiliği ve ulusdevletkimlikleri arasında; mezhep kimliklerinin siyasileşmesi; ve son olarak da etnisitenin siyasette yükselişiydi.

Anahtar kelimeler: Ortadoğu, çatışma, Sykes-Picot antlaşması, Arap milliyetçiliği, mezhepçilik, etnisite.

\section{Introduction}

The Middle East has been one of world's most conflict prone regions for decades. The root cause of these conflicts is often traced back to World War I, when Ottoman rule over the region ended and borders were reshaped by a number of arrangements between Great Britain and France, some also including regional actors. These arrangements are often blamed as the source of today's conflicts because of the artificial borders they created and great power rivalries that followed in order to gain influence over the region and its resources. The agreements in question were examples of colonial arrangements and not significantly different than similar agreements between major powers in other parts of the world, such as Africa and Asia. The only clear difference we can observe does not stem from their terms but how they were applied to the Middle East. The transfer of power from Ottomans to European powers came near the end of the colonial period when idealism was on the rise and the American President Wilson's fourteen points were accepted as the guiding principles of the new era. Because the right to self-determination was not acceptable to colonial empires, these countries were forced to come up with creative solutions in order to maintain their control over these newly liberated areas. This difficulty was overcome by the adoption of the mandate system that was meant to prepare these countries for the eventual independence under the guidance of European powers. The mandate system divided the region to more manageable sized political entities distributed between Great Britain 
and France according to secret agreements made during the war, as well as the shifting balance of power in post-war period. These arrangements were often blamed for all types of problems experienced by actors in the Middle East.

The most recent descent into conflict led many, once again, to turn their attention to World War I agreements, such as Sykes-Picot agreement of 1916. We increasingly began to hear questions on whether the borders need to be modified in order to bring stability to a region that has been unstable since the departure of the Ottoman Empire. One example of these statements was by ISIS leader Al-Baghdadi who claimed that "this blessed advance will not stop until we hit the last nail in the coffin of the SykesPicot conspiracy" in July 2014 (Foster, 2016). Despite all the attention it receives, Sykes-Picot is only one of the agreements/arrangements that shaped the modern Middle East Britain's Bunsen Committee's report, Hussein-McMahon correspondence and the Balfour Declaration were other important texts at the time. All of these arrangements were made following Ottoman Empire's entry to World War I on October 29, 1914 and they all focused on the Middle East region, the largest piece of territory still in the hands of the collapsing empire.

One thing that deserves attention is that these bargains involved different actors, but also were conducted at different stages of the war. They reflected changing circumstances and often contradicted each other. Another important point is that none of these conflicting views managed to shape post-war order in the Middle East. The result was significantly different than any one of these arrangements.

A major source of criticism is that the regional system they created did not take into consideration ethnic and religious divisions and led to deeply divided nation-states in constant conflict. There are major problems with this argument. First, colonial borders around the world were the result of great power competition and often did not take ethnicity into consideration. Yet, none of the other regions appeared to experience the level of conflict Middle East did over the past century. Second, even without the war Ottoman control over the Middle East was weakening. Nationalist movements that played an important role in pushing Ottomans out of Europe were gaining strength and the Empire lacked the tools to defend itself against these new ideologies. It was clear to many that sooner or later Ottoman control would end and new entities would emerge, Arabs 
and Armenians being the prime candidates. The emergence of these new actors would necessitate the drawing of boundaries and even if they attempted to take actors' sensitivities into consideration, it seemed highly unlikely that all participants would be satisfied with the outcome. Third, and related to the first, after spending centuries under Ottoman Empire; different ethnic and religious groups had relative freedom to move around the region, leading to a population structure where each region, with very few exceptions, was heterogenous when it came to their population structure. The borders drawn in such an environment were bound to violate certain lines and divide certain groups. Finally, and most importantly, the salience of identities tend to change depending on circumstances and today's conflicts are often the result of identity realignments that we experienced over the past century and did not exist a hundred years ago.

This study attempts to provide an alternative explanation to the conflictual nature of relations in the Middle East region. While it is convenient to put the blame on the mandate system and the countries that run it, namely Great Britain and France, the issues that plague the Middle East stem from an identity structure that has become increasingly complex. The gradual politicization of identities at different levels is at the root of many conflicts we have been witnessing. The politicization of a multilayered identity structure, not only generates new conflicts at a high rate, but also makes it extremely hard to solve them individually.

I should make it clear from the beginning that this does not mean developments during World War I and the regional structure that resulted from them did not play an important role in the emergence of existing conflicts. They were the first step in a long process of identity stratification that continued with major powers' involvement during and after the Cold War. The study simply argues that it is an extremely simplistic approach to blame every conflict in the region on a series of agreements signed a century ago and were only partially applied because their terms contradicted each other. Complex conflict structures we are dealing with today would never be possible without the contribution and short sighted policies of regional actors.

\section{World War I and The Midde East}

The decade prior to World War I was a period Ottoman Empire was under constant pressure from the outside, as well as inside, and was losing 
land in all fronts. Two major causes of these losses were wars with other major powers, especially Russian Empire, and the rise of nationalism among various groups within the empire. While efforts to modernize the military proved to be insufficient, an attempt to unify the remaining population was made to avoid further domestic conflicts and land loss to independence movements. In order to create a modern citizenry the country needed a central national identity that would unite the people living within the boundaries of the empire regardless of their religious or ethnic origin. Considering the size of the empire and the variety of people living in it, this was a hard task to accomplish and Ottomans failed like many other empires.

Ottomanism was initially adopted as a response to emerging nationalist movements within the Empire, mainly in the Balkans. The aim was to unite different groups under a common identity and a rights system similar to the ones in Europe. The hope was that this would at least reduce separatist tendencies and create some domestic stability. In an international environment where national identities had already taken shape, the attempts to create an Ottoman identity came too late. By that time many national groups already identified themselves as being different from their Ottoman rulers. As a result, Ottomanism did very little to create a common identity and stop the losses especially in the Balkans. These losses required the Ottoman identity to constantly evolve in order to focus on the groups that were still a part of the Empire. Soon this became limited to the Middle East, focusing on Islam as a unifying factor.

There were two main reasons for the failure of Ottomanism. First, Ottoman system was based on the compartmentalization of the society under the "millet" system. Similar to an authoritarian consociationalism, the system allowed some degree of freedom to different religious groups to rule themselves, while all political authority was concentrated at the center. This made the Ottoman Empire a fertile ground for nationalist movements. Because the boundaries between identities were based on religious differences, most nationalist movements that emerged had a strong religious component to them, making it possible for these groups to seek and find support from other major powers. The relative appeal of an umbrella identity bringing these groups that lived separately for this long was limited at best. Second, there were already a number of nationalist movements struggling for independence and a new underdeveloped identity had a very hard time competing with these developed, separatist identities supported by external actors. In order to have a territorial national identity first you have 
to have ethnic national identities in place and willing to live together. In this sense Ottomanism was still born.

Because the emergence of new nationalisms relied on the differences they had from the central authority and that religion was still the main factor people used to shape their identity within the Ottoman territory, Middle Eastern territory remained under Ottoman control until World War I. The determining factor was the Caliphate, not the Ottoman identity. The religious component made it harder for Arabs to agree on the boundaries of a common identity that would separate them from other Muslim groups within the empire. At least initially, a significant portion of the population appeared to see the Ottoman rule as the lesser of two evils compared to the colonial powers of the time. As the war progressed, nationalism started to have an increasing impact among the more conservative and religious segments of the Arab society.

Parallel to Ottoman efforts to hold its remaining lands together, there were plans to reshape the Middle East. Bunsen Committee's report, Hussain-McMahon correspondence, Sykes-Picot agreement and Balfour Declaration $^{\mathrm{i}}$ were all parts of this process even though the terms of each greatly contradicted other. What they had in common was their effort to create alliances with local actors to bring the Ottoman Empire down, as well as make secret arrangements for the post-Ottoman period in the Middle East. Their differences were the results of the preferences of the actors involved and the external circumstances when they were created. As a result, many of their promises to local actors contradicted each other. In the following section, I will evaluate these arrangements in order to show that post-war circumstances made it extremely hard to adopt these agreements and what came out of them was a regional structure that was not only a variation of collonial structures in other parts of the world, but also none of the involved parties' optimum outcome.

\section{Key Texts That Shaped The Modern Middle East}

Despite its weakened status, Ottoman Empire's entry to World War I was an important development that could potentially alter the balance. It forced participants to re-evaluate their goals and priorities.

The record shows us that Great Britain took the lead and was influential in shaping the plans for a post-Ottoman Middle East. British 
influence was the result of two factors. First, Great Britain was very active in the region even before the war started and was interested in oil reserves throughout the Middle East. Unlike the French, whose goals were determined by their traditional ties to the region, Great Britain based its policy on two main goals: the control of the oil sources and the protection of the sea routes to South Asia. This is somewhat surprising because its was France who was experiencing an oil crisis at the time. Second, unlike Russia who struggled internally, or France who was under direct German threat, Great Britain had the luxury of looking at the war from the perspective of its potential gains and they were prepared in advance with a detailed knowledge of the region and all that it had to offer.

\section{Bunsen Committee}

British War Council created an inter-departmental committee under the chairmanship of Sir Maurice de Bunsen in order to determine British priorities about the future of Ottoman lands (Klieman, 1968). According to the report presented to the War Council on 30 June 1915, Great Britain needed to focus on nine priorities (Klieman, 1968):

- A final recognition and consolidation of Britain's position in the Persian Gulf.

- Prevention of discrimination of all kinds against British trade in areas then belonging to Turkey and the maintenance of existing important markets for British commerce there.

- Fulfillment of pledges given, or under consideration, to the several shaikhs of the Arabian peninsula.

- Security for the development of "undertakings in which we (Great Britain) are interested," such as oil production, river navigation, and construction of irrigation Works.

- Development of the grain supply which an irrigated Mesopotamia could be expected to provide, and of a possible field for Indian colonization. 
- Retention of the strategic position in the eastern Mediterranean and the Persian Gulf, plus security for British communications, with the minimum increase of naval expenditure and responsibility.

- To ensure that Arabia and Muslim Holy Places would remain under independent Muslim rule.

- A satisfactory solution to the Armenian problem.

- A settlement of the question of Palestine and the Holy Places of the Christendom.

The committee saw four possible outcomes following an Allied victory (Klieman, 1968): partition, zones of interest, Ottoman independence, and the decentralization of authority under a continuing Ottoman rule. Out of these four, the report recommended the preservation of the Ottoman Empire where power would be decentralized, because the Committee believed that this outcome would create four advantages for Britain:

- "If there is any vitality in the Ottoman Empire and any possibility of its continuance except as an international fiction," it would give the peoples of the Empire a full opportunity to help themselves.

- It was felt to be in harmony with the political theories of the allies and would encourage the hopes cherished by both Arabs and Armenians.

- If it proved unworkable, there would remain the nucleus of future independent Turkish, Armenian and Arab states.

- By granting local autonomy in Palestine, the complex question of jurisdiction over the Holy Places could be left in an unprejudiced position.

This recommendation was inconsistent with a number of the goals listed above. Because the Ottoman Empire were seen so fragile that it might 
be unable to maintain control over its Middle Eastern territories, as another possibility, partition was also evaluated in the report (Klieman, 1968):

- Greater freedom to restore and develop the swamped and buried wealth of Mesopotamia.

- Mesopotamia as a British territory would provide a granary in time of emergency.

- It would give an unrestricted opening for British commerce and industry, and "we could develop oilfields and establish Indian colonists with reference solely to our own interests and convenience".

- It would mark a definite limit to any Russian advance southwards, while if left under a weak government Mesopotamia would encourage such expansion.

- Similarly, partition would put an end, once and for all, to the German dream of a road to India from Berlin, via Vienna, Sofia, Constantinople, and Baghdad, and settle the fate of German concessions.

- It might form the basis for a definite and final settlement.

It appears that despite the recommendations of the Bunsen Commission, partition was the option selected by the War Council. There may be three reasons for this. First, it reorganized and solved all issues in Ottoman territory at once and did not leave any problems to deal with in the future. Second, it allowed Great Britain direct control in order to achieve its goals especially in the Middle East. And finally, a partition made it possible to share the benefits with Britain's allies reinforcing their involvement in the war effort. This view gained increased support with British need for an increased French involvement in the region in order to break Ottoman resistance. It, however, should be taken into consideration that many of the priorities listed in the report changed over the course of the war as a result of arrangements made with other actors and changing circumstances. The first important direct contact with regional actors appeared between British 
High Commissioner to Egypt Henry McMahon and Sharif Hussein of Mecca.

\section{Hussein-McMahon Correspondence}

In an attempt to find support his claims to estblish an independent Arab nation under his rule in all the areas with Arab population, Sharif Hussein of Mecca initiated contact with Henry McMahon, the British High Commissioner to Egypt. The correspondence started in July 1915 and lasted until January 1916 (CJPME, 2011).

It is clear from the beginning that the two sides had a significantly different interpretation of the term "independence" and the extent of territory that should be included. While Sharif Hussein was asking for an independent Arab state that appeared to be unrealistically large.

Great Britain believed that the Arabs for some time to come were bound to need European assistance and protection (Friedman, 1970). Clearly, what Great Britain meant by independence was the end of Ottoman rule over Arabs, only to be replaced by the dominance of European powers. Great Britain needed to find a balance between Hussein's demands, their needs and the concessions they would have to make to France. The incompatibility of these interests was one of the reasons that necessitated the secret nature of the Sykes-Picot agreement later on.

This difficulty led to the disagreement over Syria early during the negotiations. Great Britain refused to include Syria to the independent Arab state for two reasons. There were two reasons for this (Friedman, 1970). First, they had already recognized French interests in that part of the Middle East and did not believe France would be willing to make concessions. Second, they argued that Syrian Arabs had sided with the Ottomans during the war and that this showed that Hussein did not enjoy the widespread support he had claimed.

It is clear that at one point during the negotiations British authorities changed their position and decided to concede to some of Hussein's demands. ${ }^{\text {ii }}$ There may be two additional motivations that led British authorities to change their position. First, as I have mentioned earlier, Syria was a region where Sharif Hussein did not enjoy as much support as he did elsewhere. The inclusion of Syria to an independent Arab state would 
strengthen anti-Ottoman feeling in these provinces and weaken the limited support Ottomanism enjoyed there. Second, it seemed that Hussein's position within the Arab world was tenous at best and in the absence of an alternative leader to cooperate with Britain may have chosen to boost Hussain's credibility and speed up the process in order to achieve its goals before its regional coalition fell apart.

Muslim population's cooperation with British authorities was already strained in India after Britain had declared war on Ottoman Empire (Friedman, 1970). British cooperation with Hussein was seen as another threat to the survival of the Ottoman Empire, but more importantly to the Caliphate. Adding to these strains was the unpopularity of Hussein among the pilgrims throughout the Muslim world. It was clear that British cooperation with Hussein could potentially cause problems in other Muslim colonies as well as the rest of the Middle East. From this point of view, it made sense for Great Britain to reach its regional goals as quickly as possible in order to avoid having to deal with additional complications in other parts of the world.

As a result, British promised an independent Arab state between Iran and Egypt. In turn, Arabs would revolt against the Ottomans. McMahon's proposal excluded modern day Lebanon, and accepted the proposed borders as long as they coincided with the territory where they could make the decision independent of French interests (CJPME, 2011). This statement gives priority to any agreement the British would make with French authorities over their promises to Hussein, meaning that Hussein's plans for Syria and Lebanon were bound to go unfulfilled.

Sharif Hussein - McMahon correspondence and the deal that came out of it was inconsistent with the realities of the region. Instead of focusing on nationalist groups that were secular and predominantly urban, Great Britain sought to deal with Sharif Hussein and his family that represented traditional power strucures. The choice may be the result of a combination of the following reasons. First, because of their control of Holy Places, and despite of his unpopularity among other Muslims, Hussein had the potential to appeal to all Muslims, not just the Middle East. Second, unlike small urban nationalist groups, Hussain commanded a fighting force that could rebel against the Ottomans and help British goals. And finally, these urban secular groups were less likely to tolerate continued British influence in the region once the war ended. This alliance proved to be effective in not only 
creating an Ottoman-free Middle East, but also creating regimes dependent on continued British support long after the war.

\section{Sykes-Picot Agreement}

French influence in the Ottoman Empire in general, and Syria and Lebanon in particular, had very deep roots. Especially during the 19th century as a result of French government's subsidies for missionary work in Far and Middle East, French religious influence was on the rise in the region through the establishment of clerical schools, hospitals, asylums and orphanages (Shorrock, 1970). Up until the 20th century French efforts did not face serious competition from other major powers, namely Great Britain, Germany and Italy. This lack of competition allowed France to strengthen its influence in other areas as well.

France controlled $62.9 \%$ of the Empire's public debt; owned the Imperial Ottoman Bank, which acted as the state bank, with Great Britain; operated several ports and docks along the Medditerranean, Black and Red seas (Shorrock, 1970). French investment in the Empire was ranked first at more than double of Germany, which was in second place (Shorrock, 1970). As a result, the future of the Ottoman Empire was an important issue. Even after it became clear that the empire was likely to collapse, French sought ways to continue their presence in the region. Syria and Lebanon were key to French interests because these were the areas where they had established very strong ties over the past centuries.

Great Britain lacked the economic ties and interests like the French, but their presence in Egypt and the need to protect their connection to Far East was enough motivation to control a large chunk of the Middle East. An additional goal for the British was the control of oil rich regions. British interest in oil had led them to research oil reserves throughtout the region. This made for these two countries to clarify the position and expectations, leading to an agreement that played an important role in post-war Middle East.

The agreement reached in May 1916 between Mark Sykes and François Georges-Picot ${ }^{\text {iii }}$ following secret negotiations at Cairo and St. Petersburg was an agreement between two colonial powers of the time that believed that the Middle East would be better off under the control of European empires. ${ }^{\text {iv }}$ The agreement divided the region to five zones that 
consisted of one under direct British control at southeast, one under direct French control at northwest, and two buffer zones in the middle that would be under British and French influence. The fifth was the Palestine which would be an international zone (Osman, 2013). In oder to satisfy Muslim sensitivities and at least some of Sharif Hussein's demands, both powers guaranteed that they would neither take over of the Arabian Peninsula, nor would they allow a third party to take possession.

Over the past century, the criticism of this agreement focused on three issues (Osman, 2013). First, the agreement was secret and went against the promises made to Arabs during the early 1910s. It was clear that neither party had any intention of keeping the British promise of independence in exchange for an Arab rebellion against the Ottomans. The thinly veiled colonial structure established after the war was seen as the source of authoritarian regimes that emerged after the independence and are still in control in many of the countries in the region.

The second criticism was about the choice of drawing straight border lines. Ottoman "millet" system had led different religious communities to live separately, making it possible to draw boundaries somewhat based on religious differences. Sykes and Picot's initial intention was to create a state system that would reflect these differences (Osman, 2013). Lebanon would be a state for Christians and Druze, Syria would be home to Sunni Muslims, and the Bekaa valley between the two countries would be left to Shia Muslims. A similar arrangement was thought of for Jews in Palestine. The borders that resulted from the agreement consisted of straight lines that did not reflect these differences. The division of these communities resulted in multi-ethnic societies that were heavily repressed under authoritarian regimes that relied on and represented one of these communities.

The third issue was the creation of an identity struggle. This could be easily seen in Syria where it took place between nationalism and secularism on one hand, and Islamism on the other. Similar divisions existed almost in all parts of the region and these lines led to a number of conflicts in countries that emerged.

As early as 1917, the conflicting nature of promises was recognized by the British. French plans to create a system similar to what they had in place in Tunisia relied on the selection of locally ruling Emirs that separated 
Syria and northern parts of modern Iraq from Sharif Hussein's independent Arab state.

This made it necessary for the agreement to remain secret until after the war. On November 23, 1917 copy of the Sykes-Picot agreement, as well as other secret treaties, was published by Izvestia and Pravda, followed by their publication by the Manchester Guardian on November 26, 1917. The embarrassment of this revelation led the British and French to announce an Anglo-French Declaration in November 1918 which pledged that Great Britain and France would "assist in the establishment of indigenous Governments and administrations in Syria and Mesopotamia by setting up national governments and administrations deriving their authority from the free exercise of the initiative and choice of the indigenous populations." This declaration was far from being satisfactory because it meant that Sharif Hussein would have to be supported in all the regions he wanted to expand his state to.

On September 30, 1918, supporters of the Arab Revolt declared their loyalty to Hussein, who had been declared "King of the Arabs" by some of the religious leaders at Mecca. Later, on March 8, 1920 a Pan-Syrian Congress met in Damascus and declared an independent state of Syria with King Faisal, son of King Hussein, as the head of state and Prince Zeid, his brother, as the Regent of Mesopotamia. While the San Remo Conference recognized this declaration of independence, it placed these regions under a mandate regime, but the French decided to govern Syria directly under their own mandate and intervened militarily before the League of Nations could reach a decision, deposing King Faisal. This led the British to do the same in Palestine. Hussein's rule over the region was already shrinking even before it was established.

Even though these structural arrangements were not in the agreement, Britain went along with France's actions. One reason for this was the British need for French support. By bringing France in, Great Britain greatly reduced the length of the front between itself and Ottoman Empire. It also transferred much of the fighting on French shoulders by pushing their potential area of influence deep into the Anatolia.

A second reason, was the general logic of colonial administrations. Colonial powers were unable to commit large military forces to all the regions they controlled. This made it necessary to cooperate with indigenous 
groups in order to rule these lands. Traditionally these groups were disadvantaged minority groups. The need was to create regions where minorities would become majorities to form pockets of support that would help control the region in the long run.

\section{Stratified Identities}

Post-World War I system in the Middle East was not a period during which we witnessed the emergence of new identities. Almost all of the identities and divisions were present before. Instead, the removal of the Ottoman presence that forced these groups to live together marked the beginning of a long process that led to the politicization of these identities and the eventual creation of this complex conflict structure that plagues the region today.

By 1918, there were two relevant identity dimensions in the Middle East. The first was religion. The Ottoman millet system, based on religious communities, had been the base for identification for centuries. Because the region was predominantly Muslim, other religious groups lived as small pockets throughout the region. There were also various sectarian divisions. The second dimension was the reemerging Arabness that was also the majority, but was divided within itself based on religion, sect and region.

With the creation of nation-states territorial identities were added to the mix, followed by sectarian identities with Iran's Islamic Revolution, and finally ethnic identities by the end of the Cold War. To be clear, I do not argue that these identities were recent inventions. They were present in the region for centuries, but only became a part of the political struggle after major regional developments. As I will show in the following section the emergence of these identities as competitors on the political scene created a series of conflicts that are extremely hard to sort out individually.

\section{The Challenge of Arab Nationalism}

Arab nationalism emerged as an opposition movement to the Ottoman control like many others before it. Until the end of World War I, its limited following was mostly limited to urban areas. The slow development of Arab nationalism, compared to others especially at the Balkans, can be attributed to the fact that Arabs shared a major component 
of their identity with Turks, Islam. From the start, Arabs were between these two identities. As an Arab identity emerged, it did so in two distinct strands.

One was secular and adopted a pan-ideology aiming to unite all Arabs under an independent state similar to the nation-states in Europe, where the ideas of nationalism originated from. Pan-Arabism was more heavily supported by educated urban groups with access to European ideas. They defined Arabness as a membership to a single and indivisible Arab nation and were willing to overlook any differences between Arabs.

The second strand was essentially a more traditional approach that emphasized Islam as the main characteristic of Arab identity. They argued for a need to reform Islam. In order to return to the golden age they would need to return to the original Islam. Despite the religious emphasis, the Islamic identity they supported had Arabness at its center. The golden age they attempted to return to was described as the peak of Arab civilization, not an Islamic one, ignoring the contribution of other groups to that civilization. They also argued that Arabs needed to be at the center of the global ummah because they were the first Muslims. According to Dawn, the Arab self-view developed during the interwar periods from the Islamic modernist doctrine that emphasized the necessity to modernize Islam by returning to the true religion of Arab ancestors (Dawn, 1988). In order to distinguish between these two strands, I will call this religious version of Arabism, the traditionalist approach.

A good example of the traditionalist Arab identity and the evolution of the idea can be found in Rida's writings. Rida's Arab nationalism was mostly limited to religion and culture. Politically, he believed that Arab nationalism's usefulness was its unifying power over Arab tribes and Ottomanism, as a much wider identity, should take preference. Rida's political demands from the Ottoman administration were limited to autonomy and reform for all Arab provinces (Haddad, 1997). Prior to World War I, Rida criticized the Committee of Union and Progress for abandoning the idea of Ottomanism in favor of Turkish nationalism. He argued that the emphasis should be on the independence of Islam from foreign powers and the preservation of an "Islamic temporal power" (Haddad, 1997). This could be achieved through the solidarity of the ummah led by the Caliph.

The main point these two strands agreed on was the definition of the Arab homeland which was described as the lands where Arabs lived. 
Especially urban intellectuals saw the level of tribal solidarity as their greatest weakness and the main source of foreign influence over Arab people (Dawn, 1988).

After it became clear that the Empire may not survive the war Rida's goal shifted to creating an Arab Caliphate that would stretch from "the Red Sea, Bahr El-Arab, Persian Gulf, frontiers of Persia and Anatolia and the Mediterranean Sea" (Haddad, 1997) and would take over the task of protecting Islam against foreign powers. This shift placed his views closer to the Sharif Hussein. In order to reach that goal, Rida first negotiated with the British but failed to get the guarantees he sought. By 1916, Rida adopted two seemingly contradictory paths simultaneously. On the one hand, he supported Sharif Hussein's Arab revolt and, on the other hand, announced his loyalty to the Ottoman caliphate. He argued the revolt was a preemptive move to protect the Arabian peninsula (Haddad, 1997).

While these two strands were in competition with each other prior to World War I, following the fall of the Ottoman Empire traditionalists started to adopt Arabism in an effort to establish an Islamic state that would rule over Arab lands. This, however, did not mean these two former competing ideologies were united. Other than the independence they sought from the Ottomans and the territory they sought, they had very little in common. Traditional strand sought a return to the core values of Islam and a traditional state structure to oversee it. Pan-Arabists nationalists, on the other hand, envisioned a state structure similar to the ones in Europe. By the end of the war it became clear to everyone that neither side would achieve its vision. Instead, the region they defined as their homeland was divided among a number of nation-states. This division did not end existing disagreements, but moved them to the domestic political arena of each newly established state, where they would also have to contend with tribal and national identities. Once the Middle East was divided under the guidance of Great Britain and France, these powers and the regimes they put in place faced strong opposition from a variety of sources.

In order to ensure their control in the region, these powers needed the cooperation of locals and there were three candidates. Ottoman elites were still present and somewhat influential, but their continued influence would be interpreted as betrayal by the Arabs who fought with the Allies in order to bring them down. Pan-Arabists posed a threat by seeking a different design for the region, as well as by questioning the legitimacy of the new 
rulers. Their demands for real independence, regardless of the feasibility of their goals, was an important threat for the existence of these regimes and the interests of European powers. The third option was sub-state actors that did not have region-wide ambitions and would be satisfied with a share of the power within existing boundaries. These were the tribes that also possessed a large share of the military potential since Sharif Hussein's initial alliance had also relied on them.

Traditionalists, by that point, were divided between pan ideologies and the nature of the state they wanted. Some joined pan-Arabists, but most took part in the alliance between the new rulers and various tribes. The ones that joined pan-Arabist camp saw the creation of an Arab state as the first step on uniting the global ummah. Others who sided with the newly established traditional regimes had a number of reasons for their choice. First, they were already ideologically close to Sharif Hussein who, through his sons, ruled a number of these nation-states. Second, some saw these new states as a step in the process of ending Western influence over Islamic lands. And finally, the lifestyle these traditionalist regimes promised was much closer to what they had in mind than the one included in pan-Arabist plans.

Once these coalitions determined the sides of the conflict, these new states needed an identity that would distinguish themselves from other Arabs and unite their population. Civic national identities were the solution to that problem. In order to justify their existence, they started to emphasize their differences and this brought them into direct conflict with panArabists.

This meant that these quasi nation-states needed a new identity that would help these new states survive. The threat they faced came from two sources. The first came from traditional power structures like former elites and tribes that saw these states as artificial entities created and supported by foreign powers. The second source of challenge came from urban centers where secular Pan-Arabists still saw the unification of Arab people as a plausible goal and continued their struggle to replace these regimes with national ones as a first step.

Pan-Arabists became the opposition in all newly created Arab states to the extent the political structure permitted. Combined with the general disappointment with authoritarian regimes collaborating with Western 
powers, they formed powerful movements some of which even managed to overthrow these traditionalist regimes. Dawn points out that not only there was a connection between Arabist movements from different countries, but also that by the mid-1930s Arabism was a major trend in politics (Dawn, 1988). This cooperation did not mean that Arabist ideology was the same in all these countries. However, despite their differences, they posed a threat to established order and the foreign powers that supported it.

The regional system that came out of this competition was a twolayered identity structure where loyalty toward the nation-state had to compete against the loyalty toward the Arab nation (Pan-Arabism). The only time the latter gained the upper hand was when a common foreign threat emerged, like the creation of Israel.

In other times, differences between these countries were significant enough that pan-Arabism remained as an abstract idea and that efforts to implement it failed to gain traction. Even today, we observe political movements that mention Arab unification as one of their goals, but these movements rarely enjoy any support.

\section{The Rise of Political Islam and Sectarian Politics}

A more recent division began during the early 1980s. Even though divisions within Islam have been present since the beginning, their politicization at the regional level came much more recently. Traditionally, the centuries long initial axis of conflict has been between Sunni and Shi'a branches and has been a source of conflict since soon after the death of Prophet Mohammad in 632. Today, a more useful division can be made between three main branches: Sunni, Shi'a and Wahhabi (Mozaffari, 2007). ${ }^{\mathrm{v}}$

The presence of different sects even within each main branch and the competition between them is not new for the Middle East. The conflicts between communities over sectarian identities go back for centuries, but it was the politicization of sectarian identities at the national level and the emergence of Islamism as a legitimate contender in national politics created a longer lasting, and potentially more destructive conflict by introducing a new layer politicized identity. Hashemi describes the Islamic Revolution of Iran as "the key regional development that deeply shaped the rise of sectarianism" (Hashemi, 2016). 
Until 1979 the balance in the region was based on the competition between authoritarian republics supported by the Soviet Union and traditional regimes supported by the United States, regardless of ethnic or sectarian identities. Within this framework, US' regional policy heavily depended on the cooperation between Iran and Saudi Arabia, one with a large population and military power and the other with financial means. The revolution broke this alliance and created new lines for a balance where the Soviet Union predominantly supported Shia regimes, such as Iran and Syria and the US focused on the Sunni side, including Egypt and Iraq, who were former Soviet allies. This, in a way, legitimized sectarian conflicts as a part of international politics in the region.

Iranian Revolution had a two-sided impact on the domestic politics of regional actors. On the one hand, it inspired various opposition groups by showing that religion could be a feasible ideological alternative to the secular ideologies existing authoritarian regimes relied on. These conservative opposition groups, regardless of their sectarian origins, saw that Islam had the power to dethrone authoritarian leaders and organize the society according to religious principles. This was the case in most republican authoritarian regimes. On the other hand, traditional regimes in the region, and especially around the Gulf, had claims on some form of religious authority and saw this development as an opportunity to rally their citizens against internal and external threats. Externally, the Iranian efforts to export the revolution to other countries with significant Shi'a population could only be balanced by emphasizing Sunni identity and mobilizing the population around it. Saudi Arabia's efforts to counter the Iranian threat focused on describing the Revolution as a Shia distortion of Islam, and started to push for its own version (Hashemi, 2016). Domestically, interpretation and selective application of Islam into politics appeared to be a good method for blocking demands for democratization, as well as keeping Islamist opposition at bay.

Regardless of their motives, Middle East's authoritarian regimes began an uneasy relationship with sectarian Islamist movements and Islamist politics they supported. Initially, the threat they posed was ranked lower than secular opposition and they were tolerated in most countries. Because these regimes focused their repression efforts on others, Islamist movements gradually became better organized and more powerful than their competitiors, giving them an important advantage when authoritarian regimes began to fall. At the same time Soviet occupation of Afghanistan 
and the rise of Mujahedeen supported by Saudi Arabia and the US allowed these movements to create international networks. This allowed these groups to not only communicate and cooperate with each other, but also for countries to use them as tools of international politics.

Mozaffari (2007) argues that "despite some important differences and even reciprocal animosity among Sunni, Shi'a and Wahhabi Islamists, they have more in common than in opposition." He mentions their belief in the authoritarian character of Islam and their ultimate goal of creating a global Ummah as their common traits (Mozaffari, 2007). The fact that "they share the same ideals, practice the same methods and nourish the same patterns of solidarity and animosity towards the external world" is seen as a source for a potential strategic alliance between these groups (Mozaffari, 2007). The opposite seems more plausible and better fitting to what we have observed so far. Even though these groups share the characteristics Mozaffari (2007) lists, their interpretation of Islam and the Ummah they want to build significantly differs from one another, pushing them to conflict and allowing them to justify their existence using the other two.

The end of the Cold War was the last stage where groups (ethnic, terrorist, etc.) increasingly found opportunities to become international actors due to the weakening of central authorities as a result of decreasing support from major powers. This created a second domestic dimension, making conflict lines even more complicated.

\section{Ethnic Identities in Politics}

The last dimension added to this already complex puzzle was ethnic identity. Just like sectarian identities, different ethnic groups lived along side each other and came into conflict with each other from time to time. The emergence of ethnicity as a conflict dimension in the Middle East coincided with a similar trend in other parts of the world. The end of the Cold War was a time for ethnic resurgence around the world. Middle East was not an exception.

The shift from a bipolar system allowed new actors to emerge and make an impact on politics domestically and internationally. Ethnic groups were among these new actors and had an advantage over others because their mobilization efforts targeted a group that had built in mechanisms for maintaining and mobilizing it at a much lower cost. Despite this important 
advantage, they had failed to become relevant during the Cold War because of the pressure applied by authoritarian regimes. While such regimes often tend to favor one of the ethnic groups in society, thus making them ethnically based, their control over the military allowed them to repress others effectively.

The end of the Cold War meant a decline of support for authoritarian governments because superpowers no longer needed to compete over allies in order to achieve global dominance, or balance. The reduction of military and economic aid limited authoritarian leaders' ability to resist domestic challenges to their rule. Ethnic groups used this opening for increasingly mobilizing their members around their demands. These divisions proved to be extremely easy to exploit by other actors because it was clear that postWorld War I nation states had succeeded in emphasizing their differences from others, but failed to create identities that would unite around.

\section{Conclusion}

Today, Middle Eastern regional system consists of nation-states with conflicting interests. But there are four additional dimensions of conflict, two above and two below the nation-state level. Above, we have two competing Pan ideologies: Pan-Arabism and Pan-Islamism. Pan-Arabism's failure to bring Arabs together over the past century makes it only a little more than a romantic idea, just like other pan-nationalist ideologies around the world. It does not pose a major threat for the regional actors, maybe with the exception of the Arab-Israeli conflict. The same is also the case for panIslamism. Islam, like others, is a deeply divided religion and even if one focuses solely on a single branch, a number of different interpretations exist. Even though this makes pan-Islamism as unrealistic as pan-Arabism as a political ideology, pan-Islamist ideas are likely to continue finding support until this is proven. For an Islamic union the first requirement is the control of individual countries by Islamist governments. Only after that, steps can be taken toward a union and it becomes clear that no such union is possible. As result, pan-Islamist ideas are likely to be a source of conflict in domestic politics for the time being.

At sub-national level, there are two competing identities: ethnic and sectarian. Because these identities cross-cut each other, it becomes extremely hard to predict where people's loyalties lie, raising the level of uncertainty in domestic political competition. A high level of uncertainty, 
combined with this multi-layered identity structure increases the probability of conflict and goes a long way to explain Middle East's past century.

Sykes-Picot Agreement and events that preceded it such as the Hussain-McMahon correspondence and the Balfour Declaration were the first step in the creation of the "Modern Middle East," but it would be a gross overstatement to blame them as the sole source of the conflicts we are observing today. The events that led to the existing problems came in stages. Middle East was not the only region that went through a colonization period and experienced frequent great power intervention. Some parts of Asia and Latin America, as well as virtually the whole African continent suffered as a result of conflicts that resulted from arbitrarily drawn boundaries. Out of these, Africa's troubles seem to be the most similar to the Middle East. However, while African conflicts appeared to peak during the early 1990s, followed by a period of stability, Middle East continues its descent into chaos.

Here, I argued that this was the result of stratified identities that are cross-cutting and at the same time competing for individuals' loyalties. These identities create a complex structure that makes it extremely hard to solve individual conflicts. Post-World War I arrangements were the first step of this process, but it would be an oversimplification to emphasize them as the main cause. The emergence of national identities that sought to develop a civic nationalism, politicization of sectarian identities and the increased salience of ethnicity all played an important role in determining the circumstances we found ourselves in.

It would also be naive to ignore the role external actors played in the process. The choices they made and their interventions on behalf of their allies made a difference and continues to do so. As a result, these interventions periodically and significantly altered the regional balance of power.

In my opinion, the role of these external actors is only surpassed by nation states' inability to develop national identities that could bring different groups together under a common identity. This failure was the result of their efforts to justify and legitimize their rule by emphasizing differences from others. Developments showed us that the assumption that unity cannot be achieved through the definition of the "other" alone. Where we stand today, these problems became chronic and interrelated, making it 
almost impossible to solve them individually. Radical efforts, such as redrawing the borders, can achieve very little more than introducing new layers of conflict. Instead, a strong show of support for existing borders, as well as strengthening national identities appear to be the most reasonable path to regional stability.

\footnotetext{
${ }^{i}$ Balfour Declaration was one of the main documents of the period and deserves attention. However, because the Creation of Israel is one of the few instances that other united regional actors, and that the issue is beyond the scope of this study, I will not further focus on the Balfour Declaration.

${ }^{i i}$ Friedman (1970) argues that what changed British position over the boundaries of the Arab state was the interrogation of Muhammad Sherif al-Faruqi, an Arab officer from the Ottoman army belonging to a young Arab secret society called al'-Ahd. He argues that Al-Faruqi revealed that his fellow officers were negotiating with Ottomans and Germans for an independent Arab state, but they trusted British more and would be willing to support the British cause if they received guarantees within a few weeks. According to al-Faruqi "the point on which the Young Arabs would not budge, was the inclusion of Damascus, Aleppo, Hama and Homs in the Arab Confederation. In the absence of a better explanation, Friedman's argument still seems far from convincing as the sole cause of a policy shift.

iii Tsarist Russia was also represented by Sazonov and were given the control of "Asia Minor, including Istanbul, Armenia and Northern Kurdistan." Following the Bolshevik Revolution the terms of the agreement were revealed, causing anger among the Arabs (Suleiman 2016).

${ }^{\text {iv }}$ While Russian Empire was present during the negotiations the Bolshevik Revolution ended Russian involvement in the war and kept Soviet Union out of the implementation stage.

${ }^{\mathrm{v}}$ Even though Wahhabism is a version Hanbali School (one of the four schools of Sunnism) because it is significantly different from other Sunni sub-sect Mozaffari (2007) argues it can be treated as a separate branch (Mozaffari, 2007).
}

\section{References}

\section{Books}

Isaiah Friedman, The Question of Palestine, 1914-1918 (London, 1973)

\section{Articles}

Aaron S. Klieman, "Britain's War Aims in the Middle East," Journal of Contemporary History, 3 (3), July 1968, 237-251.

Canadians for Justice and Peace in the Middle East (CJPME), "The MaMahon-Hussein Correspondence," Factsheet series No. 140, October 2011 (29.03.2016).

Ernest Dawn, "The Formation of Pan-Arab Ideology in the Interwar Years," International Journal of Middle East Studies, 20 (1), February 1988, 67-91. 
Isaiah Friedman, "The McMahon-Hussein Correspondence and the Qustion of Palestine," Journal of Contemporary History, 5 (2), 1970, pp. 83122.

Mahmoud Haddad, "Arab Religious Nationalism in te Colonial Era: Rereading Rashid Rida's Ideas on the Caliphate," Journal of the American Oriental Society, 117 (2), April-June 1997, pp. 253-277.

Mark Levene, "The Balfour Declaration: A Case of Mistaken Identity," The English Historical Review, 107 (422), January 1992, pp. 54-77.

Mehdi Mozaffari, "What Is Islamism? History and Definition of a Concept," Totalitarian Movements and Political Religions, 8 (1), 2007, pp. 1733.

Nader Hashemi, "Toward a Political Theory of Sectarianism in the Middle East: The Salience of Authoritarianism over Theology," Journal of Islamic and Muslim Studies, 1 (1), 2016, pp. 65-76.

Steven L. Foster, "The Historical Implications of Defining Sovereignty in the Middle East, 19.01.2016 (29.03.2016).

William I. Shorrock, "The Origin of the French Mandate in Syria and Lebanon: The Railroad Question, 1901-1914,” International Journal of Middle East Studies, 1 (2), April 1970, 133-153.

\section{Internet Sources}

Adel Suleiman, "Will the Sykes-Picot Agreement Collapse?" Middle East Monitor 21.01.2016, https://www.middleeastmonitor.com/articles/ middle-east/23471-will-the-sykes-picot-agreement-collapse (27.03.2016).

\section{News}

Tarek Osman, "Why Border Lines Drawn with a Ruler in WWI Still Rock the Middle East," BBC News, 14 December 2013 (26.07.2016). 


\section{Geniş Özet}

\section{Ortadoğu'da Çatışmanın Kaynakları: Sınırlar mı, Katmanlı Kimlikler mi?}

Bölgenin Birinci Dünya Savaşı sonunda Osmanlı kontrolünden çıkmasının ardından geçen yüzyılda Ortadoğu çok sayıda çatışmaya sahne oldu. Bunların önemli bir bölümü bugün hala çözüme ulaşmamış durumda. $\mathrm{Bu}$ alandaki çalışmaların bir kısmı sözkonusu çatışmaların kaynağı olarak savaş sonunda yapılan düzenlemeleri göstermekte. Bu düzenlemeler mevcut dini ve etnik farklılıkları dikkate almadan keyfi biçimde çizilen ve bölgeyi Büyük Britanya ve Fransa arasında etki alanlarına bölerek bugünün çatışmalarının ortaya çıkmasında önemli rol oynamakla suçlanıyor. Bu düzenlemeler arasında özellikle Büyük Britanya'nın savaş sonrası için Ortadoğu planlarını şekillendiren Bunsen Komitesi raporu, Büyük Britanya ve Fransa arasında imzalanan ve bölgeyi etki alanlarına bölen Sykes-Picot anlaşması, son olarak da Mekke Şerifi Hüseyin ile Büyük Britanya'nın Mısır temsilcisi Henry McMahon arasındaki yazışmalar yer alıyor. Balfour Deklarasyonu bu dönemin önemli bir başka belgesi olmasına rağmen ortaya çıkarttığı çatışma ile bölgesel aktörlerin büyük bir bölümünü bir araya getirmiş olması nedeniyle bu çalışmanın kapsamı dışında kalıyor.

Yukarıda belirtilen bu düzenlemelerin modern Ortadoğu'nun şekillenmesindeki önemleri inkar edilemez. Ancak bu çalışma bugün gözlemlediğimiz çatışmaların ortaya çıkışında sınırlı bir rol oynadıklarını öne sürerek bölgede son yüzyılda siyasi bakımdan önemli hale gelen kimliklerin bu çatışmaların ortaya çıkışında daha önemli bir rol oynadığını savunuyor.

\section{Birinci Dünya Savaşı Gelişmeleri}

Birinci Dünya Savaşı'na Osmanlı İmparatorluğu'nun da dahil olması savaş sonu ile ilgili beklentilerin de yeniden düzenlenmesi ihtiyacını doğurdu. Eldeki bilgiler bize bu konuda Büyük Britanya'nın diğer müttefiklerinden daha etkin olduğunu gösteriyor. Bunun iki temel nedeninden bahsetmek mümkün. Ilk olarak savaşı kendi topraklarında yaşamayan Britanya Avrupa sahnesi dışındaki gelişmelere daha fazla dikkat edebilecek bir konumda bulunuyor ve zaten sömürgeleri ve ulaşım yolları 
konusundaki endişeleri de bunu gerektiriyor. İkinci neden ise özellikle Ortadoğu ile ilişkilerden kaynaklanıyor. Fransa bölgeyi köklü ilişkileri bakımından değerlendirirken Britanya'nın doğal kaynaklara öncelik verdiğini ve bu konuda daha ayrıntılı bilgiye sahip olduğunu görüyoruz. $\mathrm{Bu}$ nedenlerle Osmanlı'nın savaşa katılmasının ardından oluşturulan Bunsen Komitesi'nin çalışmaları önemli. Komite raporunda öncelikli olarak Osmanlı devletinin mümkün olması durumunda Britanya korumasında varlığını sürdürmesinin hedeflerine ulaşmalarını kolaylaştıracağı sonucuna vardıktan sonra ikinci bir seçenek olarak bölünmeden bahsediyor (Klieman 1968).

1915 yılının yaz aylarında kendi liderliğinde bağımsız bir Arap devleti kurmak isteyen Mekke Şerifi Hüseyin'in Britanya'nın Misır temsilcisi Henry McMahon'a ulaşmasıyla başlayan yazışmalarda ise uzun pazarlıklar sonucunda bağımsız bir Arap devleti sözünün verildiğini görüyoruz. Bu devletin sınırları ise kısmen muğlak bırakılıyor. Tarafların bu konuda birbirinden çok farklı yorumları olduğunu biliyoruz (Friedman 1970).

Bundan bir yıl sonra ise Büyük Britanya ve Fransa, Rusya'nın da katılımıyla, bir araya gelerek Sykes-Picot antlaşmasını gizli olarak imzalıyor ve Ortadoğu'yu beş bölge olarak paylaşıyorlar. İki ülke birer bölgeyi doğrudan kendi kontrol alanları olarak belirlerken, birer bölgeyi de etki alanları olarak tanımlıyorlar. Beşinci bölge olan Filistin uluslararası alan olarak tanımlanırken Arap yarımadasının işgal edilmeyeceğini belirtiyorlar. Açıkça görüldügü üzere bu düzenlemeler birçok konuda birbiriyle çelişiyor. Zaten savaşın ardından yapılan düzenlemelerin de yukarıda belirtilen belgelerde sayılan şartlara uygun olduğunu söylemek mümkün değil. Değişen koşullar Ortadoğu'da aktörlerin hiçbirinin öncelikli tercihi olmayan bir sonucun doğmasina neden oluyor.

\section{Savaș Sonrası Gelișmeler}

Savaşın ardından Ortadoğu'ya getirilen manda sisteminin 19. yüzyılın sömürge yapılarının Milletler Cemiyeti prensiplerine uygun hale getirilmiş bir versiyonundan ibaret olduğunu söylemek mümkün. $\mathrm{Bu}$ kapsamda ulus-devletler yaratılmasına rağmen bölgedeki grupların büyük bir bölümü rahatsız. Yaygın olarak iki temel ideolojinin Araplar arasında destek bulduğunu görüyoruz. Bunlardan biri seküler bir ideoloji olarak 
Avrupa'daki milliyetçi akımları örnek alan Pan-Arap milliyetçiliği, diğeri ise daha dini bir kimlik üzerinden ortaya çıkan, küresel bir ümmeti hedefleyen ve bunun merkezine Arap kimliğini koyan Pan-İslamcı hareket. $\mathrm{Bu}$ iki hareket de yeni ortaya çıkan ulus-devletlerin meşruiyetini soruluyor ve çok daha geniş yapıları hedefliyor. Bu nedenle Batı destekli geleneksel rejimler ulus-altı yapılara yönelerek topraklarındaki kabileleri ortak bir kimlik çerçevesinde birleştirmeyi hedefliyorlar. Yaratılan bu yeni kimlikler bir taraftan ülke vatandaşlarının ortak özelliklerini ön plana çıkarırken diğer taraftan öteki Arap'lardan farklılıklarına vurgu yapıyorlar. Böylece hem devlet ve devlet-üstü aktörler arasında, hem de bu yeni devletler arasında çatışmaların ortaya çıktığını gözlemliyoruz.

İkinci kırılma 1979 İran İslam Devrimi ile ortaya çıkıyor ve iki düzeyde etki yaratıyor. Devlet düzeyinde İran ve bölgedeki Sünni devletler arasında İran-Irak savaşıyla kendini gösteren gerilimlerin arttı̆̆ını görüyoruz. Aynı zamanda Suudi Arabistan gibi Sünni geleneksel rejimler kendi İslami yaklaşımlarını siyaset sahnesine sürüyorlar. Bu rekabetin devlet içi düzeye yansıması mezhep bazlı siyasetin yükselişe geçmesi ve çatışmaların artması şeklinde oluyor. Otoriter cumhuriyetlerde ise İran Devrimi o noktaya kadar hayal kırıklığı yaratan seküler ideolojilere dinin bir alternatif olabileceği şeklinde yorumlanıyor.

Son olarak, Soğuk Savaş'ın bitişi ile iki kutuplu sistemin son bulduğunu ve büyük güçlerin küçük devletlere müttefik olarak ihtiyacının azaldığını görüyoruz. Bu gelişme askeri ve ekonomik yardımlardaki azalmayla birlikte otoriter rejimleri muhalif hareketlere karşı daha zayıflatıyor. $\mathrm{Bu}$ ortamda hem grup bağlarının gücü, hem mobilizasyon maliyetlerinin düşük olması etnik grupları muhalif örgütlenmelerde ön plana çıkarıyor. $\mathrm{Bu}$ dönemde zaten karmaşık olan çatışma yapısına etnik çatışmaların da eklendiğini görüyoruz.

\section{Sonuç}

Bugün, Ortadoğu'da karşımıza çıkan karmaşık çatışma yapısı son yüzyılda siyaset sahnesine dahil olan katmanlı kimlikler ve bunların toplumları farklı şekillerde bölmesinin bir sonucudur. Ulus-devletler ikisi devlet-üstü düzeyde (Pan-Arap ve Pan-İslam), ikisi de devlet-altı düzeyde (mezhepsel ve etnik) olmak üzere dört farklı kimlikle rekabet etmek zorundadır. $\mathrm{Bu}$ karmaşık çatışma sistemi farklı alanlardaki çatışmaları 
birbirine bağlayarak tek tek çözülmelerini de engellemektedir. Ortaya çıkışlarında kendilerini diğerlerinden ayıran özelliklere vurguda başarılı olurken halklarını birleştirme konusunda aynı başarıyı gösterememiş olmaları bu karmaşık durumun ana nedenlerindendir.

Çatışmaların değerlendirilmesi sürecinde bölgeye dışarıdan müdahale eden aktörlerin rolünün de hafife alınmaması gerekir, ancak bu müdahaleleri mümkün kılan da ulus-devlet yapısının zayıflığıdır. Bu aşamada sınırların yeniden çizilmesiyle sonuçlanacak yeni bir müdahale mevcut sorunları çözmek yerine bu çatışma sistemine yeni bir boyut ekleyecektir. 